Przegląd Prawa Konstytucyjnego

-- ISSN 2082-1212--------

DOI 10.15804/ppk.2014.05.11

$-\mathrm{Nr} 5(21) / 2014--------$

\title{
Recenzja
}

\section{Jerzy Kuciński, O Konstytucji Rzeczypospolitej Polskiej z 2 kwietnia 1997 roku. Kompendium, Dom Wydawniczy Elipsa, Warszawa 2014, ss. 262}

Do zasobu piśmiennictwa prawno-konstytucyjnego przybyła w ostatnim czasie nowa pozycja wydawnicza, jaką jest recenzowana książka o wymienionym na wstępie tytule. Wśród wielu innych prac z dziedziny prawa konstytucyjnego, których przedmiotem stała się analiza treści i funkcji obowiązującej w Polsce ustawy zasadniczej z 1997 r., książka Jerzego Kucińskiego może być traktowana jako publikacja szczególna. Owa osobliwość wynika zarówno z przeznaczenia książki, jak i z jej charakteru.

Nie jest sprawą nową, że od czasu uchwalenia Konstytucji RP ukazało się wiele podręczników o utrwalonej w środowisku prawniczym renomie (wznawianych w ostatnich latach), nadto książek analizujących wybrane zagadnienia prawa konstytucyjnego ${ }^{1}$, aż po opracowania, których celem jest niesienie pomocy studentom zgłębiającym wiedzę prawniczą, politologiczną i kierunki pokrewne ${ }^{2}$. Wskazywać to może, że istnieje naturalne zapotrzebowanie na ten rodzaj literatury - co w pewien sposób związane jest

1 Do tego rodzaju książek zaliczyłbym m.in. opracowania z zakresu praw człowieka i obywatela, instytucji prezydenta, instytucji kontrasygnaty i inne. Osobno przypomnijmy, że całkiem niedawno J. Kuciński opublikował podręcznik akademicki: Ustrój konstytucyjny Rzeczypospolitej Polskiej, Warszawa 2013.

2 Z tego punktu widzenia na uwagę zasługuje przede wszystkim komentarz encyklopedyczny pt. Konstytucja Rzeczypospolitej Polskiej, red. W. Skrzydło, S. Grabowskia i R. Grabowski, Warszawa 2009, a także inne publikacje, by wymienić niektóre spośród wznawia- 
z tokiem nauczania prawa i podyplomowym doskonaleniem wiedzy prawniczej. Na odrębną uwagę zasługuje inne zjawisko, jest nim moim zdaniem aktywność naukowa środowiska prawników, politologów i specjalistów z różnych dziedzin zajmujących się wiedzą konstytucyjną albo penetrujących jej obrzeża ${ }^{3}$. Owa aktywność - jak można mniemać - wynika nie tylko z uniwersyteckich zadań badawczych, lecz nade wszystko z faktu, że ustawa zasadnicza jest tworem żywym, i ze względu na ten przymiot ma utylitarne zastosowanie w procesach społecznych i prawno-politycznych wewnątrz Polski oraz $\mathrm{w}$ relacjach prawno- międzynarodowych. W tym przypadku chodzi o nieobce prawu konstytucyjnemu zagadnienia rozmaitych rodzajów stosunków polskiej wspólnoty państwowej ze społecznościami europejskimi i światowymi. Publikacyjny dyskurs konstytucyjny inspirowany jest także przez inne czynniki. Pierwszy, to rodowód Konstytucji RP, przez jednych pojmowany jako sui generis umowa społeczna, przez innych jako dokument tolerowany bez nadmiernego entuzjazmu i zaangażowania obywatelskiego oraz emocjonalno-politycznego ${ }^{4}$. W związku z tym, w dbacie publicznej nieustannie pojawiają się postulaty - które wymagają oddzielnej uwagi - nie tyle zmierzające do stabilizacji ustawy zasadniczej, co jej zmiany, albo dostosowania jej postanowień do aktualnych zdarzeń prawnych, bądź bieżących celów i programów politycznych określonych sił politycznych.

nych, np. M. Granata, Prawo konstytucyjne w pytaniach i odpowiedziach, Warszawa 2010, M. Derlatki, Konstytucja Rzeczypospolitej Polskiej ze schematami, Warszawa 2013 i in.

3 Posługując się sformułowaniem wiedza konstytucyjna, wypowiadam się za celowością istnienia dystynkcji między pojęciami: „konstytucjonalizm” a „prawo konstytucyjne”, rozumianym zarówno jako zespół norm regulujących prawny porządek konstytucyjny, jak i przedmiot nauczania. Szerzej na ten temat W. J. Wolpiuk, Instytucja konstytucjonalizmu a prawo konstytucyjne, [w:] Instytucje prawa konstytucyjnego $w$ dobie integracji europejskiej. Księga jubileuszowa dedykowana prof. Marii Kruk-Jarosz, red. nauk. J. Wawrzyniak, M. Laskowska, Warszawa 2009, s. 146-155. Wyrażane przeze mnie przekonanie o potrzebie oddzielenia norm ustrojowych i doktrynalnie pojmowanej wiedzy konstytucyjnej od terminu konstytucjonalizm obejmującego szersze spektrum zjawisk społecznych zdaje się potwierdzać praca A. Sulikowskiego: Konstytucjonalizm a nowoczesność. Dyskurs konstytucyjny wobec tryumfu i kryzysu moderny, Wrocław 2012, s. 8 i in.

4 W. J. Wołpiuk, Inwentarium wspóttworzenia przez społeczeństwo Konstytucji RP z 1997 roku, [w:] Piętnaście lat Konstytucji RP z 1997 roku. Inspiracje, uregulowania, trwałość, red. nauk. J. Kuciński, Warszawa 2012, s. 51- 65. 
$\mathrm{Na}$ odrębne potraktowanie zasługuje nurt publikacyjny, który można uznać za ekwiwalentny wobec niedoskonałości Konstytucji RP z 1997 r. jako aktu dogmatycznego, niezwykle szczegółowego, i przez to mało elastycznego oraz powodującego trudności w zakresie stosowania go w zmieniających się krajowych warunkach rozwijania mechanizmów demokracji oraz integrowania się członków polskiej wspólnoty państwowej z demokratycznymi wspólnotami w Europie ${ }^{5}$. Składnikami tego nurtu są publikacje o charakterze deskryptywnym, komentarzowym, wykładnicze, postulatywne i niekiedy popularyzatorskie. Przyjmując, że recenzowana książka należy do tego nurtu i chcąc określić jej miejsce w literaturze prawno-konstytucyjnej, stajemy przed pewnymi trudnościami. Bo oto z jednej strony książka w podtytule zawiera wyraz „kompendium”, co oznaczać mogłoby wykonany na poziomie naukowym zarys podstawowych wiadomości o Konstytucji RP, zaś z drugiej strony Autor informuje o tym, że adresatami książki w jego zamiarze - jest szerokie spektrum odbiorców, wśród nich „„zwykli> zjadacze chleba, którzy chcieliby powiększyć swoją znajomość problematyki konstytucyjnej" (s. 9). Zauważmy, że jednanie tego rodzaju zamiarów należy do przedsięwzięć niełatwych. Zarówno ze względów metodologicznych, semantycznych, jak i ze względu na dobór treści opracowania oraz obszerność 6 . Podejmijmy zatem próbę scharakteryzowania zawartości książki, po to aby wypowiedzieć o niej uwagi.

Książka składa się siedmiu rozdziałów poprzedzonych wstępem, zakończenia i obszernego zestawienia literatury. Próbując dla celów recenzyjnych usystematyzować zawartość książki, dokonałem umownego podziału zgromadzonego w niej materiału na trzy podstawowe części. Upoważnia mnie do tego fakt, że Autor odszedł od stereotypowej architektury budowy książki, tworzonej według wzorca odzwierciedlonego w systematyce Konstytucji RP. Przeciwnie, starał się zrealizować zadanie przedstawienia ustawy zasadniczej z punktu widzenia wybranych problemów, o naturze nie tylko dogmatycznej, lecz także politologicznej, historycznej i im podobnym.

Pierwszą część stanowi w wysokim stopniu teoretyczna wiedza, o konstytucji jako hierarchicznie i pod względem znaczenia prawnego najważniej-

5 Zob. J. Osińskiego, Neoinstytucjonalizm a kierunki zmian konstytucyjnych w państwach skandynawskich. Sugestie dla Polski..., s. 283-285.

6 O niektórych tego rodzaju dylematach informuje Autor we wstępie (s. 10). 
szym akcie normatywnym w państwie. Analiza wymienionych zagadnień zawarta została w rozdziale I (Wiadomości ogólne o konstytucji jako najważniejszym w państwie akcie prawnym) i w rozdziale V (Najwyższa moc prawna Konstytucji RP z 1997 r.). O ile jednak ogólne zagadnienia o normatywnym znaczeniu konstytucji w państwie zostały przedstawione w rozdziale I z perspektywy doświadczeń światowych, to problematyki: najwyższej mocy prawnej konstytucji, jej miejsca w systemie źródeł prawa, nakazu bezpośredniego jej stosowania i innych związanych z pozycją ustawy zasadniczej kwestii, zostały wyłożone w rozdziale $\mathrm{V}$ w kontekście unormowań obowiązującej Konstytucji RP, z uwzględnieniem stanowisk wyrażonych w literaturze i niekiedy w judykaturze. Na tle od dawna obecnych w literaturze przedmiotu wypowiedzi o najwyższej mocy prawnej konstytucji, na specjalną uwagę zasługuje kwestia bezpośredniego stosowania ustawy zasadniczej, doceniona ze względu na jej nowatorski charakter. Została ona przedstawiona głównie w perspektywie nadrzędności aktu konstytucyjnego, formułującego nakazy i niekiedy zakazy oraz delegującego uprawnienia. Powiedzmy otwarcie, że mniej zorientowanemu czytelnikowi bezpośrednie stosowanie konstytucji kojarzyć się może z realnością bezpośredniego odwołania się w stosunkach publiczno-prawnych do ustawy zasadniczej, tak jak to zostało utrwalone w praktyce kultury amerykańskiej. Z treści rozdziału I można natomiast wnosić, że materia bezpośredniego stosowania konstytucji jest co najmniej niejednoznaczna i teoretycznie sporna (s. 216). W tej sytuacji odpowiedź na pytanie co nowego wnosi ustawa zasadnicza zwłaszcza dla ludzi - na skutek werbalnego zadeklarowania bezpośredniego jej stosowania, pozostaje otwarta. Jeśli nadto uwzględnimy wysoki stopień odesłań do regulacji ustawowej spraw, których źródłem są postanowienia konstytucyjne (o czym informuje Autor na s. 192-195), to na tej podstawie możemy sobie wyrobić zdanie o nader skomplikowanym charakterze instytucji bezpośredniego stosowania konstytucji.

Do drugiej części książki umownie zaliczam rozdziały II, III, VI i VII w których przedstawione zostały wybrane zagadnienia historyczne związane $\mathrm{z}$ powstaniem i stosowaniem prawomocnych niegdyś $\mathrm{w}$ Polsce konstytucji, przedstawiony został proces tworzenia Konstytucji RP z 1997 r., omówiona została jej charakterystyka na tle konstytucji byłych państw so- 
cjalistycznych oraz naświetlone zostały zagadnienia dokonanych i planowanych zmian w obowiązującej konstytucji.

W rozdziale II (Konstytucje polskie wcześniejsze niż Konstytucja RP z 1997 r.) zostały przedstawione: Konstytucja z dnia 3 maja 1791 r. (Ustawa rządowa), dwie konstytucje uchwalone po odzyskaniu przez Polskę niepodległości w 1918 r., tzn. Konstytucja z 1921 r. (tzw. marcowa) i Konstytucja z 1935 r. (tzw. kwietniowa), tzw. „mała konstytucja” z 1947 r., Konstytucja PRL z 1952 r., akty konstytucyjne z lat 1989-1990 i tzw. „mała konstytucja” z 1992 r. W rozdziale III (Przygotowanie i uchwalenie Konstytucji RP z 1997 r.) Autor zajmuje się skomplikowanymi problemami nieskutecznych prób uchwalenia konstytucji po przemianach ustrojowych rozpoczętych ustanowieniem nowego systemu politycznego w 1989 r. Następnie charakteryzuje - niemniej skomplikowane ze względów politycznych ${ }^{7}$ - uregulowania prawne określające tryb przygotowania i uchwalenia nowej konstytucji oraz omawia przebieg prac prowadzących do uchwalenia i wejścia w życie Konstytucji RP z 1997 r. Odrębnie naświetlonych zostało kilka spornych aksjologicznie i ustrojowo zagadnień występujących w toku prac przygotowujących nową konstytucję, które zostały rozwiązane dzięki kompromisowym porozumieniom i znalazły odzwierciedlenie w treści postanowień konstytucyjnych.

Z niektórymi zagadnieniami stanowiącymi treść rozdziału III wiążą się kwestie omawiane w rozdziale VII (Konstytucja RP z 1997 r. na tle współczesnych konstytucji demokratycznych). Chociaż tytuł tego rozdziału zapowiada, że przedmiotem rozważań będą porównania materialnie względnie szeroko zakrojone, (współczesne konstytucje demokratyczne) to de facto przedmiotem porównań są konstytucje państw, które nie tylko zmieniły ustrój polityczny po 1989 r. i weszły na drogę bytu demokratycznego, lecz także stały się członkami Unii Europejskiej. Materią będącą paradygmatem porównawczym są więc konstytucje, które w rozwoju dziejowym po 1989 r. zmieniały swoją treść i których przepisy cechuje różny stopień stabilności w porównaniu do Konstytucji RP z 1997 r. oraz są rozmaicie stosowane ${ }^{8}$.

W. J. Wołpiuk, Inwentarium..., s. 53 i n.

8 Znamienny pod tym względem jest przykład Węgier. W. Brodziński podaje, że Konstytucja Węgier po dniu 25 kwietnia 2011 r. (data podpisania przez prezydenta) była szesnastokrotnie nowelizowana, przy czym niektóre nowelizacje i praktyka ustrojowa w dużym stopniu odeszły od wzorca demokracji przyjętego w standardach Unii Europejskiej. W lipcu 
Oprócz rozważań komparatystycznych, oddzielnie podjęta została kwestia implementowania do Konstytucji RP standardów współczesnych demokratycznych konstytucji europejskich. Z wypowiedzi rozdziału VII, można powziąć przekonanie, że źródłem inspirującym polską Konstytucję były nie tylko rodzime idee i wpływy, lecz także takie, które wykazują podobieństwo do rozwiązań stosowanych w ustawach zasadniczych innych demokratycznych państw europejskich. Kwestia sposobu i stopnia wdrożenia wzorców demokratycznych do ustawy zasadniczej nie jest książce szczegółowo rozważana. Trudno byłoby nie zgodzić się z taką decyzją autora, bo rozwiązania, które przyjęto w Konstytucji RP mają już swoją historię, zakorzenienie prawne i „zdały egzamin” w zakresie udziału Polski w rozwijaniu coraz ściślejszego związku z narodami i państwami demokratycznej Europy. Nie stanowi to wszakże uzasadnienia by nauka prawa nie kontynuowała badań w zakresie tzw. europeizacji ustawy zasadniczej ${ }^{9}$, po to aby formułować na tej podstawie wnioski de lege ferenda, mogące mieć zastosowanie w ewentualnej zmianie postanowień konstytucyjnych.

Zagadnienia zmian ustawy zasadniczej zostały przedstawione w rozdziale VI (Stabilność Konstytucji RP z 1997 r. a problematyka jej zmian). Podstawową tezą rozważań wokół zagadnienia zmiany Konstytucji/zmian w Konstytucji, uczynił Autor kwestię jej stabilności. Na podstawie analizy konstytucyjnych unormowań ustalających zasady zmiany ustawy zasadni-

2013 r. „Parlament Europejski - o czym informuje W. Brodziński - wydał rezolucję wzywającą władze Węgier do przestrzegania reguł demokracji oraz usunięcia niektórych nowelizacji do Ustawy Zasadniczej z 2011 r.” Zdaniem W. Brodzińskigo wiele argumentów przemawia za tym, że „Węgry dłużej nie będą demokracją w stylu zachodnim”. W. Brodziński, Ksztattowanie nowego ładu państwowego na Wegrzech - rewolucja narodowo-konserwatywna (uwagi krytyczne), [w:] Państwo demokratyczne, prawne i socjalne. Studia konstytucyjne. Księga jubileuszowa dedykowana Profesorowi Zbigniewowi Antoniemu Maciagowi, T. 1, red. M. Grzybowski, P. Tuleja, Kraków 2014, s. 218-224. Por. też wypowiedzi podczas seminarium naukowego: „Węgierska droga transformacji ustrojowej”, zorganizowane przez Katedrę Prawa Konstytucyjnego Akademii Leona Koźmińskiego w Warszawie dnia 29 maja 2014 r.

9 Przykładowo wymieńmy niektóre prace, w których podejmowana była problematyka „europeizacji” konstytucji: W. Orłowski, Zmiany w konstytucjach zwiąane z członkostwem w Unii Europejskiej, Kraków-Rzeszów-Zamość 2011; Europeizacja konstytucji państw Unii Europejskiej, red. K. Kubuj, J. Wawrzyniak, Warszawa 2011; W. J. Wołpiuk, Semantyczne, prawne i konstytucyjnoprawne aspekty pojęcia europeizacji, „Zeszyty Naukowe Wyższej Szkoły Zarządzania i Prawa w Warszawie” 2008, nr 2(29), s. 15-37. 
czej, Autor dowodzi, że przyjęte w tej sprawie zasady powodują, że procedura zmiany jest trudna do urzeczywistnienia, to z kolei upoważnia do zaliczenia Konstytucji RP do kategorii „sztywnych” (s. 223-224), ewentualnie „relatywnie stabilnych” (s. 226). Owa konstatacja stanowi tło do przedstawienia praktyki zmian w Konstytucji, które nolens volens mają znaczenie historyczne, bo zarówno te które doszły do skutku, jak i te, które były przygotowywane, należą do przeszłości. Przedmiotem rozważań w tym zakresie są zatem zarówno dokonane zmiany, jak i podejmowane próby, propozycje i postulaty zmian Konstytucji, przy czym owe zagadnienia zostały przedstawione w kontekście prac parlamentarnych i pozaparlamentarnych ${ }^{10}$.

Część trzecią książki stanowi zawartość rozdziału IV (Treść Konstytucji RP z 1997 r.). Jest to część merytorycznie najważniejsza i zarazem najobszerniejsza (mieści się w niej ok. 37\% materii składającej się na treść książki). W rozdziale IV Autor wraca na ścieżkę rozważań prawniczych o obowiązującej ustawie zasadniczej, nie abstrahując jednak w pełni od spraw w pewien sposób podnoszonych $\mathrm{w}$ innych miejscach (aksjologia, źródła inspirujące treść ustawy zasadniczej) i nie rezygnując z podejmowania kwestii teoretycznych, przejawiając w ten sposób troskę o zaspokojenie potrzeb czytelników chcących poznać złożoność unormowań konstytucyjnych w szerszym kontekście. Celowe wydaje się zauważenie, że niektóre spośród podejmowanych problemów należą do teoretycznie trudnych, niejednoznacznie definiowanych i powodujących spory w literaturze. Dotyczy to m.in.: katalogu wartości i ich znaczenia z punktu widzenia spójności ustawy zasadniczej i jej stosowania ${ }^{11}$, różnic między zasadami a wartościami ${ }^{12}$, między nimi a klauzulami

10 M. Laskowska zaproponowała podział zagadnienia „zmiany (w) Konstytucji” w oderwaniu od podmiotu, który inicjuje zmiany, na zmiany: dokonane, projektowane i postulowane. Europeizacja konstytucji..., s. 205-220. Oprócz tego jako formę zmiany rozważa zmianę treści Konstytucji w drodze jej wykładni. Ibidem, s. 205.

11 Zdaniem W. Sadurskiego Konstytucja RP oparta jest przede wszystkim na wartościach demokratyczno-liberalnych, bo wynika z nich prawo wyrażania poglądów większości w wyborach parlamentarnych i prezydenckich, a także dlatego, że skuteczne spetryfikowanie w ustawie zasadniczej wolności i praw stanowi zaporę przeciwko swobodnej władzy większości i grup nacisku. W. Sadurski, Nowemu ministrowi sprawiedliwości do sztambucha, „Gazeta Wyborcza”, z dnia 9 października 2014 r.

12 Z.Ziembiński, Wartości konstytucyjne. Zarys problematyki, Warszawa 1993; A. Pułł: Z problematyki zasad prawa: idee ogólne w prawie konstytucyjnym, „Przegląd Sejmowy” 1996, 
generalnymi; istnienia pytań o zakres tych pojęć, o znaczenie i samodzielność pewnych wyrażeń, m.in. takich, jak: idea ogólna, przewodnie założenie (s. 105-106) i inne pojęcia tworzone przez politologię oraz doktrynę prawa i niemające sensu stricto odzwierciedlenia w przepisach konstytucyjnych. Czynię tę uwagę nie w intencji kwestionowania zalet poznawczych problematyki zasad, wartości, klauzul generalnych i innych tego rodzaju instytucji, ale ze względu na trudność zrozumienia ich przez mniej przygotowanego czytelnika. Podejmowanie tych kwestii w książce adresowanej do szerokiego kręgu czytelniczego może bowiem powodować pewne trudności percepcyjne, zwłaszcza w oddzieleniu wypowiedzi doktrynalnych od ich realnych przymiotów normatywnych i skuteczności w obrocie prawnym ${ }^{13}$.

Jakjuż poprzednio powiedziano, w rozdziale IV oprócz problematyki źródeł inspiracji treści ustawy zasadniczej, przedstawienia poglądów Autora na temat systematyki (zakresu przedmiotowego) Konstytucji i jej aksjologii scharakteryzowane zostały poszczególne części aktu konstytucyjnego. Autor podjął się w tym rozdziale nie lada zadania, jakim stała się próba przedstawienia podstawowych treści Konstytucji RP (w slangu prawniczym nazywanych „instrukcją obsługi państwa”), co prawda w sposób uogólniony, ale bez utraty kwestii najważniejszych. Urzeczywistniając owo zadanie, Autor nie wiąże się w pełni ze strukturą Konstytucji, chociaż omawiając wybrane przez siebie zagadnienia i odpowiednio je nazywając, wskazuje czytelnikowi miejsce ich uregulowania. Przykładowo omawiając „Naczelne konstytucyjne zasady ustroju RP” (o których mówi, że „mają charakter zasad konstytucyjnych”), jako miejsce ich wyrażenia wskazuje rozdział I, twierdząc, że zostały one pomieszczone „uzupełniająco także we wstępie do ustawy zasadniczej”, oraz że znalazły „rozwinięcie w innych postanowieniach” (s. 107). Podobne podejście znalazło zastosowanie do treści rozdziału II Konstytucji, która została przedstawiona jako „Sta-

nr 1(13), s. 9-20; W. J. Wolpiuk, Zasady oraz wartości a jakość konstytucji, [w:] Jakość prawa, publikacja na 40-lecie Instytutu Nauk Prawnych PAN, red. A. Wasilkowski, Warszawa 1996, s. $95-108$.

${ }^{13}$ Przemawia za tym - jak się wydaje - stanowisko prof. Jerzego Wróblewskiego w sprawie postulatu przestrzegania praworządności, wyrażającym się koniecznością istnienia związku między normami będącymi składnikiem systemu obowiązującego prawa a wyprowadzanymi zeń zasadami prawa. Cyt. za M. Zieliński, Zasady i wartości konstytucyjne, [w:] Zasady naczelne Konstytucji RP z 2 kwietnia 1997 roku, red A. Bałaban, P. Mijal, Szczecin 2011, s. 23. 
tus prawny jednostki w Konstytucji”, z kolei fragment książki zatytułowany „Źródła prawa w Konstytucji” (s. 132-139) nie ograniczony został do skomentowania treści rozdziału III Konstytucji, ale podejmuje niektóre kwestie znacznie szerzej, dotyczy to np. materii ustawowych, procedur legislacyjnych, pozycji ratyfikowanych umów międzynarodowych i innych. Odmienna metoda została natomiast zastosowana do przedstawienia treści trzech rozdziałów Konstytucji (IV „Sejm i Senat”, V „Prezydent Rzeczypospolitej Polskiej” i VI „Rada Ministrów i administracja rządowa”). Zostały one scharakteryzowane łącznie, w oddzielnym fragmencie książki zatytułowanym: „Konstytucyjny system rządów” (s. 147-169). System wyborczy, referenda oraz inicjatywa ustawodawcza obywateli zostały ujęte jako wydzielony segment rozdziału IV książki (s. 140-147), zatytułowany: „Uczestnictwo obywateli w sprawowaniu władzy publicznej”. Tymczasem zagadnienia organizacji i kompetencji władzy sądowniczej (ustalone w rozdziale VIII Konstytucji) oraz właściwości organów, których pozycja konstytucyjno-prawna została uregulowana w rozdziale IX Konstytucji (NIK, RPO), przedstawiono w książce wspólnie, jako oddzielny składnik rozdziału IV zatytułowany: „Organy ochrony porządku prawnego w konstytucyjnym systemie władzy publicznej”. Przyjęcie takiego rozwiązania Autor uzasadnia tym, że ogół wymienionych organów realizuje zadania w zakresie porządku prawnego (s. 169), zauważając wszakże, że odmiennie od organów władzy sądowniczej inne podmioty (NIK, RPO i KRRiT) „wyłamują się" z klasycznego schematu trójpodziału władzy (s. 179). Wszelako o tym, czy są to dostateczne argumenty, aby inne niż wymienione w art. 10 Konstytucji RP organy aparatu państwowego zaliczyć do organów władzy, toczy się wieloletnia debata doktrynalna. Jej przebieg wskazuje na istnienie wielu wątpliwości w sprawie ujęcia (konstytucjonalizacji) w instytucji podziału władz takiego rodzaju organów, które wykonują inne funkcje państwowe niż ustawodawcza, wykonawcza i sądownicza ${ }^{14}$. Elementem kończącym wykładane zagadnienia

14 W.J. Wolpiuk, Podziat władzy w polskim konstytucjonalizmie. Od jednolitości władzy państwowej do modelu klasycznego, „Zeszyty Naukowe WSZiP im. H. Chodkowskiej w Warszawie”, Zeszyt Prawniczy VI, 2007, nr 2(27), s. 49 i n. Ubocznie zauważmy, że przedmiotem zainteresowań doktryny są nie tylko kwestie związane $\mathrm{z}$ formalnym podzieleniem władzy między określone organy, lecz także kwestie wzajemnego naruszania kompetencji ustalonych na podstawie podziału funkcji. Interesujące badania w tej sprawie prowadzi prof. E. Łętowska. W jednej ze swoich publikacji stwierdza, że zagrożenie dla czystości stosunków między władzami nie pochodzi z uzurpacyjnego „przejmowania kompetencji innych władz, 
w IV rozdziale książki stało się przedstawienie pozycji prawnoustrojowej samorządu terytorialnego („Samorząd terytorialny w konstytucyjnym systemie władzy publicznej”). Przypomnijmy zwłaszcza, że od czasu ustanowienia „małej konstytucji” nie został on konsekwentnie uwzględniany jako odrębny składnik tzw. podziału władzy. Dzieje się tak, mimo że w postmodernistycznej organizacji państw to właśnie samorząd terytorialny ma podstawowe znaczenie w rządzeniu i partycypacji w nim społeczeństwa obywatelskiego. Autor nie rozważa szczegółów tej kwestii, natomiast ogniskuje swoją uwagę na konstytucyjnych zasadach ustalających samodzielność samorządu terytorialnego i innych zasadach pozwalających wykonywać jego funkcje społeczne i prawne (s. 182-184). Architektura książki sprawiła, że zagadnienia samorządu terytorialnego stanowią zaledwie niewielki fragment (6 stron) analizowanych w niej kwestii. To niewiele, zważywszy że doktryna prawa dostrzega w działalności samorządu rozmaite negatywne zjawiska ${ }^{15}$, których źródłami są zarówno polska koncepcja samorządności preferująca administracyjny model aktywności $^{16}$, jak i sposób wykonywania prawa oraz wady wynikające z niedostatków rozwoju mechanizmów społeczeństwa obywatelskiego.

Książkę zamyka zakończenie, w którym znalazło się 18 wniosków ujmujących podstawowe opinie Autora o ustawie zasadniczej.

Jak zwykle o udatności koncepcji twórczej przyjętej przez Autora oraz o przydatności książki zdecydują odbiorcy-czytelnicy. Recenzent uznaje, że książka zasługuje na uwagę odbiorców oraz że stanowi nową i społecznie potrzebną próbę upowszechnienia wiedzy o Konstytucji RP. Jeśli służyć będzie nie tylko tym potrzebom, lecz oprócz tego spotka się z zainteresowaniem i reakcją ze strony środowiska osób specjalizujących się w prawie konstytucyjnym, to świadczyć to będzie, że włożony wysiłek w jej powstanie jest godny docenienia.

Waldemar J. Wołpiuk Wyższa Szkoła Prawa we Wrocławiu

z naruszeniem granic wyznaczanych normatywnie” ale z aktywizmu dotyczącego „reinterpretacji własnych obowiązków i instrumentów dzięki którym te obowiązki są realizowane”. E. Łętowska, Partykularyzm a podziat wtadz (dostęp w Internecie), s. 33.

15 Samorzady w Konstytucji RP z 2 kwietnia 1997 roku, red. nauk. Z. Witkowski, A. Bień-Kacała. Toruń 2013.

16 R.P. Krawczyk, Nadzór i kontrola nad samorządem terytorialnym - aspekty konstytucyjno-ustawowe i faktyczne, [w:] Samorzady ..., s. 99-100. 